\title{
Advances in drug therapy for systemic lupus erythematosus
}

\author{
Daniel J Wallace
}

\begin{abstract}
Systemic lupus erythematosus (SLE) is an autoimmune disorder that afflicts 500,000 people in the United States. There has not been a new SLE drug approved in the United States since 1958. However, a guidance document issued by the Food and Drug Administration in 2005 provided a roadmap for investigators which spawned numerous ongoing clinical trials. Among these, Belimumab, a monoclonal antibody to soluble B lymphocyte stimulator, met its primary endpoints in two large trials and will probably obtain FDA approval soon. Other promising agents targeting a variety of mechanisms of action are currently in development. This minireview highlights the latest therapies under investigation in SLE and gives an overview of the pathways that are specifically being targeted.
\end{abstract}

\section{Introduction}

Systemic lupus erythematosus (SLE, commonly referred to as lupus) is a pleomorphic, autoimmune disorder of unknown cause. Afflicting approximately 500,000 people in the United States, SLE is characterized by considerable mortality and morbidity. For example, with existing therapies, half of patients with organ-threatening disease (for example, cardiopulmonary, hepatic, renal, central nervous system or autoimmune hemolytic anemia) do not survive 20 years after diagnosis, and the quality of life for those individuals with all forms of SLE is usually seriously compromised [1]. To date, the only agents approved by the Food and Drug Administration (FDA) for SLE are corticosteroids, antimalarials and aspirin, with hydroxychloroquine being the most recent addition to this armamentarium (in 1958). Now, developments in our understanding of the underlying pathogenesis of SLE have led to promising new leads for SLE drug therapy.

SLE drug development was stunted by SLE's being a "woman's disease," inadequate SLE advocacy and mostly by the National Institutes of Health nephritis trial that ran for 20 years in the $1970 \mathrm{~s}$ and $1980 \mathrm{~s}$, which demonstrated that a mean time of 5 years elapsed before a treatment arm (intravenous cyclophosphamide versus azathioprine, prednisone alone, or a combination oral cyclophosphamide plus azathioprine) was found to be

Correspondence: dwallace@ucla.edu

Division of Rheumatology, Cedars-Sinai Medical Center, 8737 Beverly Blvd, Suite 302, West Hollywood, CA 90048, USA superior [2]. Not being that patient, the pharmaceutical industry invested its rheumatic disease resources into the rheumatoid arthritis (RA) and spondylitis pipeline, where outcomes were evident within 3-6 months. In 2005, the Federal Register published a guidance document (finalized in 2010) aimed at investigators and industry that provided a roadmap detailing what a SLE trial would need to demonstrate to shepherd a new agent to market [3]. This led to the launches of a number of trials. Many errors were made by experienced lupologists (myself included) who were new to the art of clinical trial design. This included giving both arms of a study effective treatment, including patients whose diagnosis of SLE was dubious, overestimation of flare rates resulting in underpowered studies, failure to guarantee adequate supply of a drug, faulty infusion directions, underdosing effective drugs for financial reasons and overestimating steroid requirements. This minireview critically analyzes the current state of the art in SLE drug development from a regulatory and implementation standpoint.

\section{Ground rules: Requirements for a new SLE drug}

The June 2010 FDA guidelines indicate that a candidate SLE drug should meet its primary endpoint in two adequate well-controlled trials demonstrating superiority [4]. Studies should be at least 1 year in duration, and enrollees should fulfill the American College of Rheumatology criteria for SLE. Steroid use variability should be minimized, and sparing effects, if any, should be defined. Study patients should be stratified by the severity of their 
SLE, with the British Isles Lupus Assessment Group (BILAG) 2004 [5] guidelines being the preferred index for measuring disease reduction (although the Systemic Lupus Erythematosus Disease Activity Index (SLEDAI), European Community Lupus Activity Measure (ECLAM) and Systemic Lupus Activity Measure (SLAM) are also acceptable). The document provides definitions for partial clinical response, remission, reduction in flare and increase in time to flare; encourages the use of patientreported outcome measures; and leaves the door open for biomarkers and surrogate markers (none of the current ones being acceptable) potentially applicable to shorten the duration of a trial as well as improving our measurement of disease activity. Any agent must demonstrate a satisfactory safety profile, and the document supports the use of organ-specific measures (for example, the Cutaneous Lupus Activity Disease Area and Severity Index (CLASI) for cutaneous disease), especially if the drug is efficacious for one aspect of the disease but not another. The 2010 guidance document takes into account "lessons learned" and nuances that make SLE drug development so complex.

The use of nontargeted agents: Important recent studies The overwhelming majority of agents in development are biologics. However, some nonbiological agents and drugs that are on the market for other disorders have been or are under study for SLE. A detailed discussion of these studies is beyond the scope of this minireview, but the salient points are summarized below:

1. Fish oil is ameliorative in patients with mild activity [6].

2. A large trial evaluating the efficacy of vitamin $D$ is in progress (NCT 00418507).

3. The Canadian Cooperative Consortium recently demonstrated that methotrexate is steroid sparing and has anti-inflammatory properties [7].

4. Mycophenolate mofetil is equivalent to cyclophosphamide as induction therapy for SLE nephritis and is superior to azathioprine for maintenance $[8,9]$.

5. Topical pinecrolimus and tacrolimus are effective for chronic cutaneous SLE [10].

6. Leflunomide improves SLE arthritis [11].

7. Dehydroepiandrostrone has modest effects at best in mild SLE and may diminish fatigue and bone demineralization, as well as having steroid sparing properties [12]

In summary, none of the above agents are significantly ameliorative of SLE, and none have been shown to significantly influence its morbidity or mortality when compared to other agents currently available.

\section{Targeted therapies and SLE: Current status}

Multiple mechanisms of action are being explored in a variety of targeted therapies. They are summarized in Table 1.
Table 1 Targets for new therapies in systemic lupus erythematosus ${ }^{a}$

\begin{tabular}{ll}
\hline Mechanism of action & Examples of targets \\
\hline T cells & CTLA4-Ig, modified CD40L, inhibition of \\
& ICOS \\
& Regulatory T cells: expanding CD4+CD25+, \\
& CD8+CD28- \\
& mAbs to CD20, CD22, BlyS, TACi-Ig, BAFF- \\
B cells & RFC \\
& Proteosome/plasma cells
\end{tabular}

Cytokines

Inhibition of IL-6, IL-10; TNF inhibitors

Innate immune system

Toleragens

Inhibition of IFN- $\alpha$ and IFN- $\gamma$, blockade of TLR-7 and/or TLR-9, C5a inhibition

Peptides derived from nucleosomes, splicosomes

Cell surface receptor activation inhibition

Syk kinase, sirolimus

aCOS, ; mAbs, monoclonal antibodies; BlyS, B lymphocyte stimulation; TACi-lg, immunoglobulin; BAFF-RFc, ; TNF, tumor necrosis factor; IFN, interferon; TLR, Toll-like receptor.

Immune cell-specific targets ( $B$ and $T$ cells)

Inhibition of $\mathrm{T}$ cell activation and blockade of the costimulatory pathway is a promising approach (Table 2). Abatacept, already approved for RA, appears to improve musculoskeletal SLE and has an excellent safety profile [13]. The sponsor's choice to frontload their pivotal trial with a forced steroid taper before the agent reached its maximal efficacy was unfortunate and led to the primary endpoint not being met. Bristol-Myers Squibb and the Immune Tolerance Network have nephritis trials in progress, and a new phase III trial for musculoskeletal SLE is planned. Blockade of the CD40L pathway was successful but not safe with BG9588 (because of thrombotic complications) and safe but not effective for IDEC [14,15]. New

\begin{tabular}{lll}
$\begin{array}{l}\text { Table } 2 \text { Important agents currently enrolling patients in } \\
\text { clinical trials for systemic lupus erythematosus as of } \\
\text { November } \mathbf{2 0 1 0}\end{array}$ & \\
\hline Target & Trial & Comment \\
\hline T cells & NCT007744752 & Abatacept \\
& NCT00774943 & Amgen 557 ICOS inhibitor \\
B cells & NCT00660881 & Epratuzumab (anti-CD22) \\
& NCT00624338 & Atacicept blocks BlyS and APRIL \\
& NCT01162681 & A-623 blocks BlyS and APRIL \\
& NCT01205348 & LY2127399 blocks BlyS \\
Toleragen & NCT01085097 & Laquinomod \\
& NCT01135459 & Lupuzor tolerizes splicosome \\
Innate immunity & NCT00962832 & Rontalizumab inhibits IFN- $\alpha$ \\
& NCT01164917 & Amgen 811 targets IFN- $\gamma$ \\
& NCT00960362 & NNCO152 targets IFN- $\alpha$ \\
Cell surface receptor & NCT01031836 & MEDI-545 targets IFN- $\alpha$ \\
\hline
\end{tabular}

aCOS, ; BlyS, B lymphocyte stimulation; APRIL, ; mTOR (mammalian target of rapamycin). 
agents targeting different epitopes which interrupt this pathway are being studied. Amgen 557 is an ICOS-B7RP1 (Inducible Costimulator B7-RPI are receptor sites) inhibitor under evaluation in a phase II trial. Efalizumab, an LFA-1 inhibitor (Lymphocyte function associated Antigen-1), was withdrawn from the market in 2010 because of concerns with progressive multifocal leukoencephalopathy, and its cutaneous SLE trial was suspended. A phase I safety study of an agent which promotes $\mathrm{T}$ regulatory cells (Treg) has been presented [16].

$B$ cell depletion via the anti-CD20 rituximab (Roche, Basel, Switzerland) was not successful in EXPLORER or LUNAR "generalized lupus" or nephritis-specific designed studies where all patients were given high doses of corticosteroids and immune suppressives as well $[17,18]$. Case series clearly suggest that rituximab ameliorates hemolytic anemia, thrombocytopenia, arthritis and probably central nervous system vasculitis associated with SLE. Trials with humanized anti-CD20 s (for example, ocrelizumab (Roche), Trubion's (Trubion, Seattle, WA, USA) small molecule immunopharmaceutical, or SMIP (Small Molecular Immunopharmaceutical); (Pfizer, New York, NY, USA) were halted for economic, safety or design reasons, and none are in progress at this time. Anti-CD22 is a less potent B cell depletor that internalizes cell signaling promoting proinflammatory actions. A phase II dose ranging and safety study with epratuzumab (UNIM Chemique Belge (UCB), Belgium, Brussles) showed significant improvements in BILAG scores, and a phase III trial will start in late 2010 [19].

Belimumab (Human Genome Sciences, (Rockville, MD, USA)/Glaxo Smith Kline, (Uxbridge, UK) is a fully human monoclonal antibody that selectively targets and inhibits soluble B lymphocyte stimulation (BLyS), resulting in autoreactive B cell apoptosis. Using an FDAendorsed responder index that includes improvement in the Systematic Lupus Erythematosus Disease Activity Scale (SLEDAI) score, no new BILAG organ system occurrences and no worsening in physician assessments, phase II and phase III trials significantly met this endpoint among over 3,000 treated patients that resulted in an application for approval to the FDA in June 2010 [20-22]. BLyS and A Proliferatiave Inducing Ligand (APRIL) are ligands for receptors BAFF-R (B Cell Activation Factor), BCMA (B Cell Maturation Associate) and TACI(Transmembrane Activator and Calcium Reproducing Initiator). Agents blocking these components in addition to BlyS (or inhibiting membrane BlyS in addition to soluble BlyS) are being studied. These include LY2127399 (Lilly), atacicept (in phase III trials; Merck-Serono), BR-3Fc blockade (Biogen, Cambridge, MA, USA) and A-623 (Amgen/Anthera, Hayward, CA, USa). As with belimumab, these drugs primarily target developing $B$ cells and have minimal actions on the bone marrow or plasma cells. Bortezomib and carfilzumib are small-molecule inhibitors used for multiple myeloma. These agents block plasma cells, and SLE clinical trials are on the drawing board.

In summary, agents which block the action of $\mathrm{T}$ and $\mathrm{B}$ cells are already being used off-label for SLE, and several drugs in development will probably be available within the next few years.

\section{Anti-inflammatory targets: Anti-TNF, cytokines, toleragens and cell surface receptor inhibition}

Many patients with RA who have SLE overlap disease have been treated with anti tumor necrosis factor products [23]. Only infliximab has been studied to any extent in pure SLE. Synovitis can be helped, but extraarticular manifestations may worsen and anti-DNA, anticardiolipin levels can appear or increase.

Anakinra (anti-IL-1Ra) is not effective for SLE, but tociluzumab (an anti-IL6) was quite potent in a 16patient open label phase I trial at the National Institutes of Health [24]. An anti-interleukin (IL)-6 (CNTO 136; Johnson \& Johnson, New Brunswick, NJ, USA/Centocor, Horsham, PA, USA) nephritis trial is due to start in late 2010. IL-10 can have favorable or unfavorable effects in SLE because of its pleomorphic properties; however, a favorable phase I safety trial of an anti-IL-10 (Schering, Berlin, Germany) is not likely to lead to further development because of its numerous contradictory actions. Promising strategies in murine SLE include inhibition of IL-12, $-17,-18,-21$ and -23 , which may have translatable effects in humans.

La Jolla Pharmaceutics (La Jolla, CA, USA) LJP394 (Riquent) was an anti-anti-DNA B cell toleragen and edratide (TEVA, Petach Tikva, Isreal) a toleragen to the anti-16/6 anti-DNA idiotype [25,26]. Both were safe in trials involving hundreds of patients, but neither was effective enough to warrant further investigation. Laquinomod ( TEVA) has been tested in over 3,000 patients with multiple sclerosis and inflammatory bowel disease and appears to shift Th1 to Th2. An arthritis and nephritis trial was begun in late 2010. Lupuzor (Cephalon, Frazer, PA, USA) is a splicosomal peptide with U1 snRNP that promotes tolerance by preventing the proliferation of CD4+ T cells, as well as promoting secretion of IL-10 and decreasing anti-DNA in a European study. A phase IIb study is in progress.

Syk kinase inhibits intracellular kinases, and its clinical efficacy was demonstrated with R788 (Rigel, South San Francisco, CA, USA) in phase III RA trials [27]. There are plans to study this agent in SLE. Sirolimus (rapamycin) binds the regulatory kinase mTOR and is used for renal transplant rejection prevention. Many SLE patients with transplants currently take this agent, and a phase II trial is in progress. 


\section{Innate immunity, including complement}

Monoclonal antibodies to C5a were studied and shown to be safe in a phase I trial a decade ago with eculizumab (Solaris/Alexion, Cheshire, CT, USA), an agent now available for paroxysmal nocturnal hemoglobinuria [28]. A newer preparation from Novo Nordisk (Novo Nordisk, Bagsvaard, Denmark). had its SLE trial halted due to concerns relating to neutropenia in control patients.

Toll-like receptors (TLRs)-7 and -9 in immature dendritic cells are activated by complexes of self-protein and RNA or DNA. These complexes are normally rapidly cleared but accumulate in SLE because of clearance defects. TLR-7 and -9 activation induces secretion of interferons and promotes inflammation. Antimalarial drugs target TLR-7 and -9, and the development of a small oral molecule with similar actions has generated great interest from several companies (for example, ESAI (Woodcliff Lake, NJ, USA), Coley (Dusseldorff, Germany)/Xiphon (New Castle, Delaware, USA)/Pfizer (New York, NY, USA)). Medi-545 (sifalimumab; Medimmune (Gaithersburg, MDm USA)/Astra Zeneca (Wilmington, DE, USA)) and rontalizumab (Roche) can decrease the $\alpha$-interferon signature within days by $90 \%$ by looking at protein and gene expression and clear lesions in serial skin biopsies in phase I studies $[29,30]$ (Table 2). They are currently in phase III trials. NNC0152 (Novo Nordisk) and Neovasc are further behind in development, as is an agent which targets $\gamma$-interferon (AMG 811; Amgen).

\section{Summary and Conclusions}

Providing industry with a guidance document has revolutionized SLE clinical trial development. It is likely that the first SLE drug to be approved in over 50 years will be marketed in 2011. Numerous other promising approaches are being considered that will improve the morbidity, mortality and quality of life of patients with SLE. These agents may decrease or make unnecessary the use of toxic agents such as steroids or immune suppressive agents. The above approaches will influence mild and organ-threatening disease, as well as having niche properties translatable into clinically relevant outcomes.

\section{Competing interests}

Dr Wallace has performed clinical trials and/or consulted for Biogen, Amgen, Bristol-Myers Squibb, Roche, Cephalon, UCB, Merck/Serono, Novo Nordisk, Alexion, Centocor, Esai, TEVA, Rigel, Human Genome Sciences and Lilly.

Received: 29 July 2010 Accepted: 29 November 2010

Published: 29 November 2010

\section{References}

1. Wallace DJ, Hahn BH, (Eds): Dubois' Lupus Erythematosus. 7 edition. Philadelphia: Lippincott Williams \& Wilkins; 2007

2. Decker JL, Steinberg AD, Reinertsen JL, Plotz PH, Balow JE, Klippel JH: NIH conference: systemic lupus erythematosus: evolving concepts. Ann Intern Med 1979, 91:587-604.
3. U.S. Food and Drug Administration: Guidance for Industry on Systemic Lupus Erythematosus: Developing Drugs for Treatment [http://www.fda.gov/ohrms/ dockets/dockets/05d01-6/05d0106.htm], Accessed July 28, 2010. Also available at Federal Register 70(59):15868, March 29, 2005.

4. U.S. Food and Drug Administration: Guidance for Industry on Systemic Lupus Erythematosus: Developing Medical Products for Treatment [http://www.fda. gov/Drugs/GuidanceComplianceRegulatorylnformation/Guidances/default. htm], Accessed July 28, 2010.

5. Yee CS, Farewell V, Isenberg DA, Prabu A, Sokoll K, Teh LS, Rahman A, Bruce IN, Griffiths B, Akil M, McHugh N, D'Cruz D, Khamashta MA, Bowman S, Maddison P, Zoma A, Allen E, Gordon C, British Isles Lupus Assessment Group: Revised British Isles Lupus Assessment Group 2004 index: a reliable tool for assessment of systemic lupus erythematosus activity. Arthritis Rheum 2006, 54:3300-3305.

6. Wright SA, O'Prey FM, MCHenry MT, Leahey WJ, Devine AB, Duffy EM, Johnston $D G$, Finch $M B$, Bell $A L$, McVeigh GE: A randomised interventional trial of omega-3-polyunsaturated fatty acids on endothelial function and disease activity in systemic lupus erythematosus. Ann Rheum Dis 2008, 67:841-848.

7. Fortin PR, Abrahamowicz M, Ferland D, Lacaille D, Smith CD, Zummer M, Canadian Network for Improved Outcomes in Systemic Lupus: Steroidsparing effects of methotrexate in systemic lupus erythematosus: a double-blind, randomized, placebo-controlled trial. Arthritis Rheum 2008, 59:1796-1804.

8. Appel GB, Contreras G, Dooley MA, Ginzler EM, Isenberg D, Jayne D, Li LS, Mysler E, Sánchez-Guerrero J, Solomons N, Wofsy D, Aspreva Lupus Management Study Group: Mycophenolate mofetil versus cyclophosphamide for induction treatment of lupus nephritis. J Am Soc Nephrol 2009, 20:1103-1112.

9. Wofsy D, Appel GB, Dooley MA, Ginzler EM, Isenberg D, Jayne D, Solomons N, Lisk L: Aspreva Lupus Management Study maintenance results. Lupus 2010, 19(Suppl):27.

10. Lampropoulos CE, D'Cruz DP: Topical calcineurin inhibitors in systemic lupus erythematosus. Ther Clin Risk Manag 2010, 6:95-101.

11. Remer CF, Weisman MH, Wallace DJ: Benefits of leflunomide in systemic lupus erythematosus: a pilot observational study. Lupus 2001, 10:480-483.

12. Sánchez-Guerrero J, Fragoso-Loyo HE, Neuwelt CM, Wallace DJ, Ginzler EM, Sherrer YR, Mcllwain HH, Freeman PG, Aranow C, Petri MA, Deodhar AA, Blanton E, Manzi S, Kavanaugh A, Lisse JR, Ramsey-Goldman R, McKay JD, Kivitz AJ, Mease PJ, Winkler AE, Kahl LE, Lee AH, Furie RA, Strand CV, Lou L, Ahmed M, Quarles B, Schwartz KE: Effects of prasterone on bone mineral density in women with active systemic lupus erythematosus receiving chronic glucocorticoid therapy. J Rheumatol 2008, 35:1567-1575.

13. Merrill JT, Burgos-Varagas R, Westhovens R, Chalmers A, D'Cruz D, Wallace DJ, Bae SC, Sigal L, Becker JC, Raphupathi K, Peng LT, Kinasczuk M, Nash P: The efficacy and safety of abatacept in patients with non-lifethreatening manifestations of SLE: results of a 12-month exploratory study. Arthritis Rheum 2010, 62:377-387.

14. Boumpas DR, Furie R, Manzi S, llei GG, Wallace DJ, Balow JE, Vaishnaw A: A short course of BG9588 (anti-CD 40 ligand antibody) improves serologic activity and decreases hematuria in patients with proliferative lupus glomerulonephritis. Arthritis Rheum 2003, 48:719-727.

15. Kalunian KC, Davis JC Jr, Merrill JT, Totoritis MC, Wofsy D, IDEC-131 Lupus Study Group: Treatment of systemic lupus erythematosus by inhibition of T cell costimulation with anti-CD154: a randomized, double-blind, placebo-controlled trial. Arthritis Rheum 2002, 46:3251-3258.

16. Czeloth N, Dalken B, Engling A, Osterroth F, Aigner S, Abufarag A, Wartenberg-Demand A, Koch H, Becker C, Jonuleit H, Daniel V, Haefeli WE, Schwarz A, Hass J, Wildemann B, Uherek C: Selective activation of naturally occurring $T$ cells (Tregs) by the monoclonal antibody BT-061 as a novel therapeutic opportunity: preclinical and early clinical results. Annals Rheum Dis 2010, 69(S1):99.

17. Merrill JT, Neuwelt CM, Wallace DJ, Shanahan JC, Latinis KM, Oates JC, Utset TO, Gordon C, Isenberg DA, Hsieh HJ, Zhang D, Brunetta PG: Efficacy and safety of rituximab in moderately-to-severely active systemic lupus erythematosus. Arthritis Rheum 2010, 62:222-233.

18. Furie R, Looney RJ, Rovin B, Latinis KM, Appel G, Sanchez-Guerrero J, Fervenza FC, Maciuca R, Brunetta P, Zhang D, Garg J: Efficacy and safety of rituximab in subjects with active proliferative lupus nephritis (LN): results from the randomized, double-blind phase III LUNAR study. Arthritis Rheum 2009, 60:5429. 
19. Wallace D, Kalunian K, Petri M, Strand V, Kilgallen B, Barry A, Gordon C: Epratuzumab demonstrates clinically meaningful improvements in patients with moderate to severe systemic lupus erythematosus (SLE): results from EMBLEM, a phase Ilb study. Annals Rheum Dis 2010, 69(Suppl 3):558.

20. Wallace DJ, Stohl W, Furie RA, Lisse JR, Mc Kay JD, Merrill JT, Petri MA, Ginzler EM, Chatham WW, McCune WJ, Fernandez V, Chevrier MR, Zhong ZJ, Freimuth WW: A phase II, randomized, double-blind, placebocontrolled, dose-ranging study of belimumab in patients with active systemic lupus erythematosus. Arthritis Rheum 2009, 61:1168-1178.

21. Navarra S, llianova E, Bae SC, Guzman R, Tanasescu C, Gallacher A, Levy RA, Li EK, Thomas M, Jimenez R, Leon M, Hall S, Lan J, Kim HY, Pineda L, Zhong Z, Freimuth W, Petri M, BLISS-52 Study Group: Belimumab, a BlySspecific inhibitor reduced disease activity, flares and steroid use in patients with seropositive systemic lupus erythematosus (SLE): BLISS-52 study. Annals Rheum Dis 2010, 69(S1).

22. Furie RA, Gladman D, d'Cruz D, Zamani O, Wallace D, von Vollenhoven R, Tegzova D, Merrill JT, Schwarting A, Clarke AE, Doria AE, Sanchez-Guerrero J, Chatham WW, Manzi S, Ginzler E, Mc Kay J, Stohl W, Zhong ZJ, Hough D, Cooper SM, Freimuth W, Petri M, Belimumab : A BLyS specific inhibitor, reduced disease activity and severe flares with seropositive SLE: BLISS76 study. Lupus 2010, 19S:13.

23. Aringer M, Houssiau F, Gordon C, Graninger WB, Voll RE, Rath E, Steiner G, Smolen JS: Adverse events and efficacy of TNF-a blockade with infliximab in patients with systemic lupus erythematosus: long-term follow-up of 13 patients. Rheumatology (Oxford) 2009, 48:1451-1454.

24. Illei GG, Shirota Y, Yarboro CH, Daruwalla J, Tackey E, Takada K, Fleisher T, Balow JE, Lipsky PE: Tocilizumab in systemic lupus erythematosus: data on safety, preliminary efficacy, and impact on circulating plasma cells from an open-label phase I dosage-escalation study. Arthritis Rheum 2010, 62:542-552.

25. Cardiel MH, Tumlin JA, Furie RA, Wallace DJ, Joh T, Linnik MD, LJP 394-9009 Investigator Consortium: Abetimus sodium for renal flare in systemic lupus erythematosus: results of a randomized, controlled phase III trial. Arthritis Rheum 2008, 58:2470-2480.

26. Teva Pharmaceutical Industries Ltd.: Press release September 19, 2007. [http://www.tevapharm.com/pr/2007/pr_689.asp], Accessed July 28, 2010.

27. Weinblatt M, Kavanaugh A, Genovese M, Grossbard E, Magilavy D:

Treatment of rheumatoid arthritis (RA) with an oral syk kinase inhibitor: A 6 month randomized placebo controlled phase $2 \mathrm{~b}$ study in patients with active RA on chronic methotrexate. American College of Rheumatology 2009 annual scientific meeting, Abstract LB2 [http://acr.confex. com/acr/2009/webprogram/Paper17160.html], Accessed November 17 2010.

28. Kaplan M: Eculizumab (Alexion). Curr Opin Investig Drugs 2002, 3:1017-1023.

29. Wallace DJ, Petri M, Olsen N, Kyriou K, Dennis G, Yao Y, Jallal B, Coyle A, Zeng L, White B: MEDI-545, an anti-interferon a monoclonal antibody, shows evidence of clinical activity in systemic lupus erythematosus. Arthritis Rheum 2007, 56:S526.

30. Mc Bride J, Wallace DJ, Morimoto AY, Zhenling Y, Abbas A, Romeo M, Jiang J, Drappa J: Safety and pharmacodyamic response with administration of single and repeat doses of rontiluzmab in a phase I, placebo, controlled, double-blind, dose escalation study in SLE. Lupus 2010, 19S:15.

\section{Pre-publication history}

The pre-publication history for this paper can be accessed here: http://www.biomedcentral.com/1741-7015/8/77/prepub

doi:10.1186/1741-7015-8-77

Cite this article as: Wallace: Advances in drug therapy for systemic

lupus erythematosus. BMC Medicine 2010 8:77.

\section{Submit your next manuscript to BioMed Central and take full advantage of:}

- Convenient online submission

- Thorough peer review

- No space constraints or color figure charges

- Immediate publication on acceptance

- Inclusion in PubMed, CAS, Scopus and Google Scholar

- Research which is freely available for redistribution 